\title{
An Examination of the Teaching - Learning Process and Teaching Materials used in the Instruction of Geometry Sub-Learning Fields in a First Grade Classroom
}

\author{
Veli TOPTAȘ ${ }^{*}$
}

\begin{abstract}
This research has been conducted in order to examine the teaching materials used in the instruction of geometry sub-learning fields and teaching - learning process as stated in the Turkish Elementary Mathematics (1-5 grades) Curriculum. Case study, which is one of the qualitative research methods, has been used in this research. The participants of the research include one classroom teacher and 12 students selected via random method out of 40 students from a state primary school. The administration of the research was performed in the fall semester of 2005-2006 academic-year. Data were obtained through video recordings, interview and written documents. The results indicated that the teacher used only over - head projector as a technological teaching material, and did not provide other appropriate materials for teaching the subjects and lesson during instruction. Instead, the teacher used teaching tools and materials from the classroom environment that he / she thought as suitable. It has been also seen that the teacher used few and insufficient concrete materials in the activities within the class. The fact that the teacher did not use sufficient teaching and instructional materials affected the learning processes of the students in a negative way.
\end{abstract}

Key Words: Geometry Sub-Learning Fields, Teaching Materials, Teaching Learning Process

*Dr., Kırıkkale University, vtoptas@ gmail.com 


\section{SUMMARY}

The Rational and Importance of the Research: The facts that how Mathematics education and geometry sub-learning fields, which is one of the subfields of Mathematics, is conducted within the new curriculum, that how the learning fields within the framework of the Mathematics (1-5) Curriculum 2004 are realized in the classroom, and that how the learning of the students related to the geometry sub-learning fields take place have become important. Therefore, this research is necessary and important in terms of the examination of the teaching materials (manipulatives and other tools) that the teacher uses, learning processes of the students and determination of the learning levels of the students in the First grade of elementary school (in-class lesson conducting).

The aim of the Research: This study has been conducted in order to examine the First Grade Geometry sub-learning fields as stated in the Elementary Mathematics Curriculum for grades 1-5, to examine the teaching materials used in the process of teaching and teaching-learning processes, and determine the learning levels of the students.

Method: In the method of the research, qualitative research, which is one of the scientific research methods, special case study, which is one of the qualitative research methods, data collection tools and constant comparison technique have been used in the analysis and interpretation of the data collected.

Discussion and conclusions: The fact that the teacher does not use adequate and sufficient education and teaching materials during the instruction of the course affects and influences learning adversely and negatively. Furthermore, the fact that the teacher does not use adequate and sufficient education and teaching materials during the instruction of the course can be regarded as the indicator of the fact that the abstract knowledge are not concretized and materialized in a desired way. Especially because the first grade students are in the concrete operational level, instructing the abstract knowledge without concretizing makes the students rote learners. 


\title{
Geometri Alt Öğrenme Alanlarının Öğretiminde Kullanılan Öğretim Materyalleri İle Öğretme- Öğrenme Sürecinin bir Birinci Sınıfta İncelenmesi
}

\author{
Veli TOPTAŞ ${ }^{1}$
}

\begin{abstract}
ÖZ: $\mathrm{Bu}$ araştırma İlköğretim Matematik Dersi (1-5) Öğretim Programında yer alan 1. sınıf geometri alt öğrenme alanlarının öğretim sürecinde kullanılan öğretim materyalleri ile öğretme-öğrenme sürecini ve öğrencilerin öğrenme düzeylerini incelenmek amacıyla yapılmıştır. Araştırmada nitel araştırma yöntemlerinden biri olan durum çalışması (case study) kullanılmıştır. Araştırmanın katılımcıları, bir devlet ilköğretim okulunda görev yapan 1. sınıf öğretmeni ve 40 öğrenciden oluşan sinıftan seçkisiz (random) yöntem ile belirlenmiş 12 öğrenciden oluşmaktadır. Çalışmanın uygulaması 2005-2006 öğretim yılında gerçekleștirilmiștir. Araştırmanın verileri video kaydı, görüşme ve yazılı dokümanlar yoluyla elde edilmiştir. Araştırmada genel olarak şu sonuçlara ulaşılmıştır. Öğretmen teknolojik materyal olarak sadece tepegözden yararlanmış ve konunun amacına uygun materyali sınıfa getirmemiş; bunun yerine dersin işlenişi sürecinde sinıfta bulunan araç-gereçlerden konuya uygun olduğunu düşündüğü materyalleri kullanmıştır. Sınıfta uygulanan etkinliklerde ise çok az somut materyalin kullanıldığı görülmüştür. Öğretim sürecinde yeterince öğretim materyalinin kullanılmaması öğrencilerin öğrenmelerine olumsuz yönde etkilemiş olduğu söylenebilir.
\end{abstract}

Anahtar Sözcükler: Geometri Alt Öğrenme Alanları, Öğretim Materyalleri, Öğretme-Öğrenme Süreci.

${ }^{1}$ Dr., Kırıkkale Universitesi, vtoptas@gmail.com 


\section{Gİiș}

Bilginin hızla yenilenerek üretildiği çağımızda birey ve toplumun geleceği, bilgiye ulaşma, bilgiyi kullanma ve üretme becerilerine bağlı bulunmaktadır. Ayrıca gelişen dünyanın, bilim ve teknolojinin istemlerini karşılayan özelliklere sahip insanları yetiştirmek eğitim kurumlarının işlevidir. Bu nedenden dolayı dünyanın birçok ülkesi eğitim işlevlerini yerine getirebilmek için öğretim programlarında sürekli olarak yeniden düzenlemeler yapmaktadırlar (Balım ve Kesercioğlu, 2004). Buna paralel olarak Türk Eğitim Sistemi de diğer dünya ülkelerinde olduğu gibi sürekli olarak sorgulanmaktadır. Sorgulamanınsa çeşitli bilimsel araştırmalarla, ulusal ve uluslar arası değerlendirme raporları ile sürekli olarak yapıldığı görülmektedir. $\mathrm{Bu}$ sorgulamaya PISA, TIMSS ve PIRLS gibi uluslar arası değerlendirme raporları örnek olarak verilebilir. Bu raporlara matematik ve matematiğin alt öğrenme alanlarından biri olan geometri açısından bakıldığında Türkiye'nin de içinde bulunduğu (TIMSS ve PISA) gibi araştırma raporlarında matematik ve geometri açısından öğrencilerimizin başarı düzeylerinin istenen seviyede olmadığı görülmektedir. Özellikle matematik ve matematiğin alt dallarından olan geometri içeren konulara bakıldığında son sıralarda yer aldığımız birçok araştırmacı (Olkun ve Aydoğdu, 2003; Ardahan ve Ersoy, 2004; MEBEARGED, 2003) tarafindan da ifade edilmektedir. $\mathrm{Bu}$ ve benzeri nedenlerle programın tekrar geliştirilmesi yoluna gidilmiştir.

$\mathrm{Bu}$ değişim ve gelişim doğrultusunda hazırlanan 2004 İlköğretim Matematik Dersi (1-5) Öğretim Programı; 2005-2006 eğitim-öğretim yılında resmî olarak bütün okullarda uygulanmaya başlanmıştır. Bu programın temel yaklaşımında, öğrencilerin matematik öğrenme-öğretme sürecinde aktif katılımcı olması esas alınmaktadır. Ayrıca bu yaş grubundaki öğrencilerin çevresiyle, somut nesnelerle ve akranlarıyla etkileşimlerinden kendi düşüncelerini oluşturacakları ifade edilmektedir (Pesen, 2005). 2004 İlköğretim Matematik Dersi (1-5) Öğretim Programı, somut modelli öğrenmeye dayalı etkinlikler ile öğrencinin bizzat keşfederek ve anlayarak öğrenmesini esas almaktadır. Bu bağlamda özel olarak hazırlanması gereken modellerin yanı sıra, çocuğun çevresinde kolayca bulabileceği somut modellere de yer verilmiştir (Bulut, 2004).

Geometri alanında uygulanması gereken temel ilke, kişinin kendi ilişkiler dünyasını oluşturmada zihinsel özgürlüğünün ve akıl gücünün bilincinde olmasına yardımcı olmaktır. (Altıneğitim, 2005). Ayrıca, programda öğrencinin kavram ve ilişkileri somutlaştırarak kendine mal etmesi gibi özellikler ön plana çıkartılmaktadır. Programda, geometri alt öğrenme alanlarında somut modeller ve araç-gereç kullanılmasını istenmektedir. Çünkü soyut kavramların ve ilişkilerin öğrencilerce somutlaştırılabilmesi için mutlaka öğretim materyallinden yararlanılması gerekmektedir. Ayrıca öğrenme-öğretme sürecini ne kadar çok ve çeşitli öğretim materyalleriyle zenginleştirirsek öğrencinin öğrenmesine de o kadar olumlu katkı sağlamış olacağımız bilinen bir gerçektir. İlköğretim 1. sınıf öğrencileri için öğretim materyallinin kullanılması daha da gereklidir. Çünkü çocuklar bu yaş grubunda somut işlem döneminde olduklarından daha çok soyut olan durumlar için somutlaştırmaya ihtiyaç duymaktadırlar. Ayrıca ilköğretim 1. sınıfta öğrenilenler, 
bireylerin yaşamları boyunca kullanacakları temel bilgi ve becerilerin temelini oluşturmaktadır

\section{Araştırmanın Gerekçesi ve Önemi}

Matematik eğitimi ve matematiğin alt dallarından olan geometri alt öğrenme alanlarının yeni program içinde nasıl uygulandığı, 2004 Matematik Dersi (1-5) Öğretim Programı çerçevesinde öğrenme alanlarının, sınıf içinde nasıl işlenmekte olduğu ve öğrencilerin geometri alt öğrenme alanları ile ilgili öğrenmelerinin nasıl gerçekleştiği oldukça önem kazanmıştır. Bundan dolayı araştırma; ilköğretim 1. sınıfta (sınıf içi ders işlenişi) öğretmenin kullandığı öğretim materyalleri, buna paralel olarak da öğrencilerin öğrenme düzeylerinin tespit edilmesi açısından gerekli ve önemli görülmüştür.

\section{Araștırmanın Amacı}

Bu çalışma; İlköğretim Matematik Dersi (1-5) Öğretim Programında yer alan 1. Sınıf geometri alt öğrenme alanlarının, öğretimi sürecinde öğretim materyallerinin kullanılması öğretme-öğrenme süreçlerinin incelenmesi ve öğrencilerin öğrenme düzeylerinin tespit edilmesi amacıyla yapılmıştır.

\section{Araştırmanın Durumu}

Araştırmadaki kalıtımcılar, araştırmanın uygulama sürecinde Millî Eğitim Bakanlığı izniyle Ankara İli Merkez İlçelerinden biri olan Yenimahalle İlçesi sınırları içinde yer alan Demetevler semtindeki bir devlet ilköğretim okulundaki 1. sınıf şubelerinden biri olan 1/A şubesindeki 40 öğrenciden video kaydında görüntüye giren 12 öğrenci ve bir sınıf öğretmeninden oluşmaktadır.

\section{Araştırmanın Kapsam ve Sınırlılıkları}

\section{Araştırma;}

1. Ankara ili Yenimahalle ilçesi Demetevler semtindeki bir resmî İlköğretim Okulunun birinci sınıf bir şubesindeki öğrencilerden video çekiminde görüntüye giren öğrencilerle ve o şubenin sınıf öğretmeninin öğrenmeöğretme durumları ile;

2. 2005- 2006 eğitim-öğretim yllı güz döneminde matematik dersi öğretim programında belirtilen geometri alt öğrenme alanlarındaki kazanımların incelenmesi ile,

3. 2005- 2006 eğitim-öğretim y1lı güz döneminde matematik dersi öğretim programında belirtilen geometri alt öğrenme alanlarının işleniş süresindeki derslerle;

4. Sınıfta geometri alt öğrenme alanları ile ilgili öğretim sürecinde çekilen video kaydı; öğretmenin, geometri alt öğrenme alanları (uzamsal ilişkiler, geometrik şekiller, eşlik, örüntü ve süslemeler) ile ilgili öğretim sürecinde kullanmış olduğu öğretim materyallerini kapsamaktadır. Bunun dışındaki bilgiler çalışmanın dışında tutulmuştur. 


\section{YÖNTEM}

Araştırma nitel araştırma yönteminde kullanılan özel durum çalışması ile yapılmıştır. Veri toplama araçları ve toplanan verilerin analiz ve yorumlanmasında sürekli karşılaştırma tekniği kullanılmıştır. Araştırmada bireysel görüşme, (Individual Interview), gözlemle veri toplama tekniklerinden video kaydı ile yazılı kaynaklardan (Written Documentation) yararlanılmıştır. Gözlem tekniği olarak sınıfta geometri alt öğrenme alanları ile ilgili öğretmenin kullanmış olduğu öğretim materyalleri tespit edilmesi amacıyla video kayıtları gerçekleştirilmiştir. Geometri alt öğrenme alanları ile ilgili olarak sınıf içi öğretim sürecinde öğrencilerin yapmış oldukları etkinliklerin değerlendirilmesi ve bireysel görüşmelerle (ilk-son görüşme) öğrenme düzeylerinin tespit edilmesi için gerçekleştirilmiştir.

\section{Katılımcılar}

Ankara'nın merkez ilçelerinden biri olan Yenimahalle ilçe millî eğitim müdürlüğüne bağlı bir devlet ilköğretim okulu araştırmanın yapılacağı okul olarak belirlendikten sonra araştırmacı tarafindan okula gidilmiştir. Okul müdürü ile görüşülerek araştırma yapılacak olan birinci sınıfların kaç şube olduğu öğrenilmiştir. Video kaydı yapılacak sınıf ve öğretmenin belirlenmesi için okul müdürü ve 1. sınıf öğretmenlerin çekime uygunluk bakımından görüşleri alınarak sınıfların fiziki durumlarına bakılmıştır. Okuldaki 1. sınıf şubelerinden biri olan ve 40 öğrenci bulunan 1/A sınıfında kameranın sabit bir noktadan yaklaşık olarak 10- 12 öğrenciyi görüntülediği tespit edilmiştir. Çekim tek bir sınıfta yapılacağından diğer şubede görüntüye giren öğrenci sayısını 3-5 öğrenciyle sınırlı kalmasından dolayı 10-12 öğrencinin görüntülendiği sınıf seçilmiştir.

Sınıfta görüntüye giren öğrenciler seçkisiz (random) yöntemiyle belirlenmiştir. Video kaydı için görüntüye giren sıralarda oturacak öğrencilerin belirlenmesinde izlenen yol şu şekilde olmuştur. Sınıftaki görüntüye giren sıralara oturacak öğrencilerin belirlenmesi için bütün öğrenciler kuraya tabi tutulmuştur. Kura için 40 tane eşit kâğıt kesilip sadece 12 kâğıdın içine 1'den 12 de kadar olan sayılar yazılmış ve yazılan kâğıtlar katlanarak bir kavanozun içene konulmuştur. Kavanoz iyice karıştırıldıktan sonra öğrencilere kavanozdaki kâğıtlar çektirilmiştir. Çektiği kâğıt içinde herhangi bir sayı olmayan öğrenciler görüntüye alınmamış yalnızca 1 den 12'ye kadar yazılı olan kâğıtları çeken öğrenciler kameranın görüntüsüne giren sıralara oturmuşlardır. Araştırmada öğrencilerin isimleri kullanılmamış isimlerinin yerine öğrenciler numarayla kodlanmışlardır. Öğrenci kişisel dosyaları incelenerek katılımcı öğrencilerin hepsinin okul öncesi 1 yıllık eğitim aldıkları tespit edilmiştir.

Katılımcılardan biri olan öğretmen, Uygulama sürecindeki sınıf öğretmeni 26 yıllık mesleki kıdeme sahip olduğunu ve ilköğretimin 1. sınıfını daha önce 6 kez okutmuş olduğunu ifade etmiştir. Ayrıca öğretmen 2004 İlköğretim Matematik Dersi (1-5) Öğretim Programı ile ilgili olarak 2004-2005 eğitim öğretim yılında programın denenmesi için yapılan pilot çalışma içinde bulunan okulların hiç birinde görev almamıştır. Araştırmanın katılımcılarından biri olan öğretmen, 2005-2006 eğitim öğretim yılında programın uygulanmasından önce bütün öğretmenlere verilen 
programın uygulaması ile ilgili hizmet içi eğitim ve seminer çalışmalarına katılmıştır. Programın uygulanması için verilen hizmet-içi eğitim ve seminer çalışmalarının dışında diğer öğretmenlerden farklı olarak hiçbir eğitim almadığı öğretmen tarafindan ifade edilmiștir. Bu araștırmanın yapıldığı okulun okul müdürü tarafindan orta seviye okul grubuna girdiği beyan edilmiştir.

Araştırmanın uygulanması için öğretmenle görüşülerek geometri alt öğrenme alanları ile ilgili dersin işleniş sürecinin planlaması öğrenilmiştir. Öğretim sürecinin planlamasının öğrenilmesiyle birlikte video kaydının planlaması yapılmıştır. Öğretmenin belirttiği tarihten 10 gün önce öğrencilerin kameraya alışması amacıyla sınıfa pilot çalışma için kamera yerleştirilmiştir. Deneme çekimleri yapılarak alan uzmanları ile (çekilen video kaydının ve çekime giren öğrenci sayısının araştırmanın amacına uygunluğu vb. konularda) görüşülmüştür. Çekimlerle ilgili dönütlerin olumlu olmasıyla birlikte çekimlere başlanmıştır. Ayrıca öğrencilerin kameraya alışma süreci için sürekli sınıfta kamera sabit olarak görüntü alınacak yerde durdurulmuş ve öğrencilerin kameraya alışması sağlanmıştır. Öğrencilerin öğretim ortamından olumlu ya da olumsuz etkilenip etkilenmediğini test etmek için görüntüler uzmanlarla tekrar tekrar izlenmiştir. İzleme sonucunda görüntüye giren ve girmeyen öğrencilerin sınıf içinde (kayıt esnasında görüntüye girmeyen öğrencilerin de giren öğrencilerle birlikte parmaklarını kaldırıp tahtaya doğru hareket etmeleri ve sınıftaki bütün öğrencilerin zaman zaman yerinden kalkıp diğer arkadaşlarının yanına gittikleri bu esnada hiç kameraya doğru bakmadıkları bütün izlemelerde görülmüştür) kameranın varlığını hissettirecek bir davranış göstermemelerinden dolayı öğretim ortamına olumlu ya da olumsuz etkide bulunduğunun söylenemeyeceği ifade edilebilir.

\section{Veri Toplama Süreci ve Takvimi}

Verilerin toplanması 2005 Ekim - Kasım- Aralık ve 2006 Ocak ayları boyunca devam etmiştir. Bu tarihlere araştırmacının 10 günlük pilot uygulamaları dâhil edilmemiştir. Pilot uygulama 14. 10. 2005 tarihinde başlatılmıştır. Araştırmacı, öğrencilerin kameraya ve kendisine alışmaları için çocuklarla birlikte bütün derslere girerek kamerayı sınıftaki sabit yerinde durdurarak derslerin çekimi yapılıyormuş gibi hareket etmiștir. Video kaydını ise sadece geometri alt öğrenme alanları ile ilgili öğretim sürecinde gerçekleştirmiştir.

Öğretmenin, geometri alt öğrenme alanları ile ilgili öğretim sürecinin 23 ders saati olduğunu belirterek dersi tamamladığını ifade etmesi ile video çekimlerine 05 . 01. 2006 tarihinde son verilmiştir. Geometri alt öğrenme alanları ile ilgili öğretim süreci bittikten 10 gün sonra öğrencilerin uzamsal ilişkileri ile ilgili kazanımlarda yer alan terimlerin ne kadarını kullanabildikleri yani öğrenebildiklerini tespit etmek için son görüşme yapılmıştır. Son görüşmede de ilk görüşmede kullanılan görüşme aracı kullanılmıștır.

\section{Veri Toplama Araçları ve Verilerin Analizi}

Araştırma sürecinde çoklu veri kaynakları kullanılmıştır. Nitel araştırma yönteminde iç geçerlik önemli olduğu için “çeşitleme” metodu kullanılmıştır. Çünkü 
nitel araştırma yönteminde veri kaynakları kendi içinde geçerliliği sağlamaktadır. İnsan davranışlarını yansıtan çalışmalarda iki ya da daha fazla veri kaynăğ kullanılmaktadır (Cohen ve Manion, 1992; Ekiz, 2003). Çeşitleme ya da üçleme araştırma problemlerinin cevap bulması için çoklu veri toplama kaynaklarını kullanmaktadır (Glesne ve Peshkin, 1992; Akt. Yıldırım ve Şimşek, 2005).

\section{Görüşmelerin Yapılışı ve Analizleri}

Nitel araştırmalarda araştırmacının rolü oldukça önemlidir. Bunun nedeni nitel araştırmada araştırmacının kendisinin de "veri toplama aracı" olarak görülmesidir (Mertens, 1998). Yıldırım ve Şimşek'e (2005) göre nitel araştırmacı bizzat alanda zaman harcayan, deneklerle doğrudan iletişime geçen ve gerektiğinde deneklerin deneyimlerini yaşayan, alanda kazandığı perspektifi ve deneyimleri toplanan verilerin analizinde kullanan kişidir. Nitel araştırmada araştırmacının nesnelliği kimi çevrelerce tartışma konusu olmuştur. Tam nesnellik uğruna araştırmacının veri kaynaklarına yakın olarak elde edeceği daha geçerli bilgileri kaybetmemelidir.

Yin'e göre, (1994), durum çalışmasını gerçekleştirecek olan araştırmacı aşağıdaki becerilere sahip olmalıdır ( Akt: Yeşildere, 2006; s. 60):

- İyi soru sorabilmeli ve cevapları yorumlayabilmelidir.

- İyi bir dinleyici olmalıdır ve ön yargılarını, ideolojisini yansıtmamalıdır.

- Yeni karşılaştığı durumları bir tehdit değil firsat olarak görmesini sağlayacak ölçüde esnek olmalıdır.

- Çalışılan konu hakkında sağlam bir kavrayışa sahip olmalıdır.

- Tarafsız olmalıdır.

Araştırmada araştırmacı öğrencilerin düşüncelerini etkilemeyecek kadar uzak, elde edilecek bilgileri kaybetmeyecek kadar yakın rol oynamıştır. Araştırmacı öğrencilerin düşüncelerini ortaya çıkarmaya çalışan tarafsız bir rol benimsemiş̧ir.

$\mathrm{Bu}$ araştırmada öğrencilerle iki defa görüşme yapılmıştır. İlk görüşme dersler işlenmeden on gün önce gerçekleştirilmiştir. Sınıfta öğretim süreci bittikten on gün sonra bir görüşme daha yapılmıştır. Yapılan bu görüşme son görüşme olarak gerçekleştirilmiştir. Görüşmede kullanılan sorular literatürde yapılan çalışmalardaki ölçeklerden yararlanarak ve araştırma konusuna uyarlanarak hazırlanmıştır.

Öğrencilerin uzamsal ilişsilerle ilgili ön bilgilerini derinlemesine belirlemek amacıyla öğrencilerle birebir mülakatlar yapılmış ve bu mülakatların ses kayıtları alınmıştır. Görüşme yapılan öğrenciler ise video çekiminde yer alan yani görüntüye giren öğrencilerden oluşmaktadır. Ses kayıtları araştırmacı tarafından yazıya dökülmüsşür. Araştırmada verilerin analizinde benimsenen "sürekli karşılaştırma metodu"na uygun olarak gerek duyulduğunda aynen alıntılar ya da yorumlar yapılmıştır. 


\section{Sınıf İçi Ders Video Kayıtlarının Yapılışı ve Analizi}

Video kaydı, istenildiği ve gerektiği kadar izlenebildiği için, araştırmacı uygun yaklaşım ve vurgulanacak noktalar hakkında emin oluncaya kadar son kararını vermeden önce ertelemesi mümkündür. Eğer gözlem alan notları tek veri kaynağı ise, bu mümkün değildir. Zira notların alındığı ortam kısa sürer, unutulur. Fakat videonun bu kolaylığı araştırmacının ağırdan alması anlamına gelmemelidir. Malzemenin nasıl kullanılacağı konusunda net bir fikir sahibi olunmalıdır. Araştırmacı, videoda ileri geri sararak nadir veya sık olayları bulabilir, bir olay hakkında hemen karar vermeden öncesine ya da devamına bakarak yorumlarını değiştirebilir veya düzeltebilir; anahtar özellikleri yakalayabilir (Plowman, 1999). Araştırmacı analizlerini gerçekleştirirken nadir gerçekleşen olaylar ya da sık gerçekleşen olaylar hakkında olayların devamına veya öncesine bakarak yorumlarını oluşturmuştur.

Araştırmacı tarafından video kaydı, "Video Kaydından Önce (Görüntünün en iyi şekilde ayarlanması, öğrencilerin yerleştirilmesi, vb.) ", "Video Kaydı Esnasında", "Video Kaydından Sonra" ve "Kayıtları İzleme" şeklinde belirtilen ölçütler doğrultusunda gerçekleştirmiş̧ir.

Video kaydı çözümlemesi sürecinde ilk olarak, araştırmacı tarafından videoya kaydedilen görüntüler ve konuşmalar yazılı bir doküman haline getirilmiştir. Bundan sonraki aşamada yazılı dokümanı kontrol etmek amacıyla görüntüler tekrar izlenmiştir. $\mathrm{Bu}$ sırada video ders kayıtlarında çeşitli nedenlerden dolayı (aşırı gürültüden vb.) olmayan, ancak ders sürecinde gözlemlenen bazı ayrıntılar araştırmacı tarafindan dokümana eklenmişsir.

Öğrenci Etkinliklerinden Oluşan Yazılı Dokümanların (Sınıf İçi Ders İşleniş Sürecinde Yapılan Etkinlikler) Analizi

Nitel araştırmada gözlem ve görüşmenin olanaklı olmadığı durumlarda veya araştırmanın geçerliliğini artırmak amacıyla, görüşme ve gözlem yöntemlerinin yanı sıra, çalışılan araştırma problemleriyle ilişkili yazılı ve görsel materyal ve malzemeler de araştırmaya dâhil edilebilir. Bu demektir ki, doküman incelemesi veya analizi tek başına bir araştırma yöntemi olduğu gibi, diğer nitel yöntemlerin kullanıldığı durumlarda ek bilgi kaynağı olarak da işe yarayabilir. Öte yandan, nitel araştırmalarda gözlem ve görüşme gibi diğer veri toplama yöntemleriyle birlikte kullanıldığında "üçlü veri" amacına hizmet edecek ve araştırmanın geçerliliğini önemli ölçüde artıracaktır (Yıldırım ve Şimşek, 2005).

Öğrencilerin geometri alt öğrenme alanlarından geometrik şekiller, uzamsal ilişkiler, eşlik ve örüntü ve süslemelerle ile ilgili öğretim süreci içinde yapmış oldukları etkinliklerinden oluşan dokümanlar toplanmıştır. Bu yazılı dokümanlarda değerlendirme soruları ve konularını günlük hayatla ilişkilendirmeler yazılı doküman olarak toplanan veri kaynaklarıdır. Alınan yazılı dokümanlar ihtiyaç duyulan durumlarda aynen alıntı yapılarak ya da yazılı dokümana atıfta bulunarak analizi ve yorumları yapılmışıır. 
Etkinliklerin analizinde şu aşamalar kullanılmıştır: Önce, etkinliğin gerçekleşmesi için öğrencilerden istenenler tespit edilmiştir. Bunların doğrultusunda yapılmış olan etkinlik incelenmiştir. İnceleme sürecinde istenenlerle öğrencinin yapmış oldukları karşılaştırılmıştır. Karşılaştırma sonucunda öğrencinin etkinliği gerçekleştirip gerçekleştiremediği ile ilgili bilgiler yazılı doküman haline getirilmiştir. Analiz edilen etkinliklerden elde edilen yazılı dokümanlar, bunları kontrol etmek amacıyla alınan uzman görüşleri doğrultusunda gerekli değişiklikler yapıldıktan sonra tekrar düzenlenmiştir. Etkinliklerden elde edilen yazılı dokümanlar araştırmanın alt problemlerine göre kategorize edilerek tasnif edilmiştir.

\section{Verilerin Analizi ve Yorumlanmasında Kullanılan Yöntem}

Verilerin analizi ve yorumlanmasında araştırılan konuyu açıklayıcı, verilerin yüksek bir seviyede yorumlanmasını sağlayan "Sürekli Karşılaştırma tekniği benimsenmiştir. Sürekli karşılaştırmalı veri analiz metodu ilk kez Glasser ve Strauss (1967) tarafindan ortaya konmuş ve birçok araştırmacı tarafindan daha da geliştirilerek kullanılmıştır (Lincoln ve Guba, 1985; Strauss ve Gorbin, 1990, 1998; Merriam, 1998). Pek çok nitel veri analizinde tümevarım yöntemi kullanılmaktadır. Yani birey, olay ya da olgulardan bütüne ulaşmayı sağlamaktadır. Veriler önceden düzenlenmiş belli sınıflandırmalara göre analiz edilip yorumlanmasından ziyade veriler elde edildikten sonra kategorilere ayrılmaktadır (Ekiz, 2003).

Strauss ve Gorbin (1998) sürekli karşılaştırma veri analizini geliştirerek detaylı bir şekilde açıklamışlardır. Bu metodun verilerin analizinde bir takım çözümleme araçları bulunmaktadır. Bunlar: açık, aksial ve seçici kodlamadır.Genel bir anlatımla sürekli karşılaştırmalı veri analizi, incelenen verilerin tümevarım kategori şeklinde kodlanması ve aynı zamanda incelenmekte olan verilerle sürekli olarak karşılaştırılması işlemini kapsamaktadır. Bu karşılaştırma işleminde benzerlikler gösteren ya da benzer anlamları kapsayan veriler kalmadığında, yeni bir kategori oluşturulur. Böyle durumlarda oluşturulan bazı kategoriler verileri tam olarak yansıtmadığı gerekçesi ile çıkarılır (Strauss ve Gorbin, 1998).

\section{BULGULAR ve YORUM}

Bulgular, nitel araştırma desenlerinden biri olan durum çalışması desenine uygun olarak ulaşılan verilerin analizi ile elde edilmiştir. Analiz sonucu verilerden elde edilen bulgular; açık kodlama, aksial (birleştirme) kodlama ve seçici kodlama tekniklerinden yararlanılarak oluşturulmuştur. Elde edilen bulgular doğrultusunda yorumlamalar yapılmıştır.

İlköğretim 1. sınıf öğretmeninin, geometri alt öğrenme alanlarını (uzamsal ilişkiler, geometrik şekiller, eşlik, örüntü ve süslemelerin), öğretim sürecinde kullanılan öğretim materyalleri ile öğrencilerin öğrenme düzeyleri ile ilgili bulgular ve yorumlar aşağıda sıralanmaktadır. 


\section{Uzamsal İlișkiler}

Öğretmenin, geometri alt öğrenme alanlarından biri olan uzamsal ilişkilerle ilgili öğretim sürecinde kullandığ öğretim materyalleri ve öğrencilerin öğrenme düzeyleri ile ilgili bulgular ve yorumlar aşağıdadır

“Öğretmen: Elime bu silgiyi allyorum. Bu nedir?

Ögrenciler: Silgiiii

Öğretmen: Tahta silgisini şuraya koydum. Tahta silgisi şimdi nerede çocuklar?

Öğrenciler: Dolabın üstünde”

Bu diyalogda öğretmenin, öğretim materyali olarak tahta silgiden yararlandığ görülmektedir.

“Öğretmen: Bu Nil sözcüğ̈̈ bu da nine sözcü̆ğ̈̈...

(ögretmen bu iki sözcügü tahtaya yapıştırdl)

Öğretmen: Nil ve nine sözcükleri tahtanın neresinde? Tahtanın neresinde? Neresinde?

Öğrencilerden biri: Biri aşă̆ısında biri yukarısında"

$\mathrm{Bu}$ diyalogda da sinıfta bulunan okuma yazma araçlarından kelime bulutlarından yararlanılmıştır.

"Öğretmen: Şimdi çocuklar bir beslenme çantasını hedef alıyoruz. Buna göre bunun içinde kalanlar. Bunun altında kalanlar."

Yukarıdaki diyalogda da öğretmen sınıfta bulunan beslenme çantasını öğretim materyali olarak kullanmaktadır.

"Öğretmen: Peki, yazı tahtasının yukarısında kelime bulutlarının yukarısında ne var?

Öğrenci: Atatürk

Ögretmen: Başka ne var Emirhan?

Emirhan: Gençliğe hitabı

Öğretmen: Gençliğe hitabl, Eylül?

Eylül: Türk bayrăğ var."

Yukarıdaki diyalogda da öğretmenin, sınıftaki demirbaşları öğretim materyali olarak kullandığı görülmektedir.

"Öğretmen: Çocuklar ben size sayfanın numarasını söyleyeceğim. Kitabımızı açacağız tamam mı? Ders kitabını açıyoruz, 10 yazan sayfayı açıyoruz.

(Öğrenciler ders kitaplarındaki sayfayı açtılar.)

Öğretmen: Peki, çocuklar şiiiş̧̧s.. O kitabınızı kapatın çocuklar. Diğer çalışma kitabınızı çıkarın. Arkasında böyle bir adam resmi var(eliyle resmi işaret ederek). Sayfa 5 çocuklar! Sayfa beşi açar mısınız?" 
Bu diyalogda, öğretmenin, öğretim materyali olarak ders kitabından ve çalışma kitabından yararlandığı görülmektedir.

“Öğretmen: Stnıfa evet önce üstteki bulutun içini incelemenizi istiyorum (resim tepegözde yansitılır.) Dikkatli baklyorsunuz. Sonra da size sorular yönelteceğim. Siz de cevaplayacaksınız, ama parmak kaldırarak. Şöyle bir rahat arkanıza yaslanın. Dikkatli inceleyiniz."

Burada, öğretmen, ders işleme sürecinde teknolojik materyal olarak tepegözden yararlanmaktadır

“Öğretmen: Şimdi çocuklar tepegözümüzü kapatıyoruz. Ben size kâğlt vereceğim. Benim söylediklerimi dikkatli dinleyerek o kâğttlara söylediğim varlıkları yerleştireceksiniz. Tamam mı?"

$\mathrm{Bu}$ diyalogda öğretmenin, öğretim materyali olarak öğrencilerine kâğıt ve kalem verdiği görülmektedir. Bu diyaloglardan elde edilen uzamsal ilişkilerle ilgili bulgular şu şekilde özetlenebilir: Geometri alt öğrenme alanlarından biri olan uzamsal ilişkilerde sınıfta bulunan silgi, dolap, beslenme çantası, sınıfta bulunan demirbaşlar ve okul laboratuarından alınan tepegöz öğretmen tarafından öğretim materyali olarak seçilmiştir. Ayrıca etkinlik içinde öğretmenin öğrencilere öğretim materyali olarak kâğıt ve kalem kullandırdığı görülmektedir. Bu bulgular sonucunda öğretmenin dersin işleniş esnasında sınıf içinde var olan araç-gereklerden yararlanma yoluna gittiği ifade edilebilir.

Tablo 1. Uzamsal İlişkilerle İlgili Öğrencilerin İlk ve Son Görüşmede Doğru Kullandıkları Terim Sayıları

\begin{tabular}{lccccc}
\hline & İ. G. D. & S. G. D. & U. I. P. & Ö. S. S. & Ö. S. S. \\
& K.T. S. & K.T. S. & $\begin{array}{c}\text { T. S. } \\
\text { K. T. S. }\end{array}$ & D. K. T. S. \\
\hline Öğrenci 1 & 5 & 9 & 17 & 4 & 8 \\
Öğrenci 2 & 8 & 17 & 17 & 9 & - \\
Öğrenci 3 & 7 & 11 & 17 & 4 & 6 \\
Öğrenci 4 & 5 & 12 & 17 & 7 & 5 \\
Öğrenci 5 & 8 & 14 & 17 & 6 & 3 \\
Öğrenci 6 & 9 & 12 & 17 & 3 & 5 \\
Öğrenci 7 & 7 & 11 & 17 & 4 & 6 \\
Öğrenci 8 & 7 & 14 & 17 & 7 & 3 \\
Öğrenci 9 & 9 & 10 & 17 & 1 & 7 \\
Öğrenci 10 & 7 & 12 & 17 & 5 & 5 \\
Öğrenci 11 & 7 & 10 & 17 & 3 & 7 \\
Öğrenci 12 & 7 & 13 & 17 & 6 & 4 \\
\hline
\end{tabular}

İ. G. D. K.T. S. = İlk Görüşmede Doğru Kullandığı Terim Sayısı

S. G. D. K.T. S. = Son Görüşmede Doğru Kullandığı Terim Sayısı

U. İ. P. T. S. = Uzamsal İlişkilerle İlgili Programdaki Terim Sayısı

Ö. S. S. K. T. S. = Öğretim Süreci Sonunda Kazandıkları Terim Sayısı

Ö. S. S. D. K. T. S. = Öğretim Süreci Sonunda Doğru Kullanamadıkları Terim Sayısı 
Uzamsal ilişkilerle ilgili olarak öğrencilerle yapılan görüşmeler ilk ve son görüşme tablosu (Bkz: Tablo 1) incelendiğinde ilk görüşmede, öğrencilerin (hazır bulunuşluk seviyesi) doğru kullandıkları terim sayısının ortalama 7 terim olduğu görülmektedir. Programda verilen 17 terimden 7 terimi öğretim sürecinden önce doğru kullanabildikleri görülmektedir. Öğretim süreci sonunda ortalama 12 terimi doğru kullandıkları görülmektedir. Öğretim süreci içinde öğrencilerin 5 terimi daha kullanır hale geldikleri anlaşılmaktadır. Fakat programda verilen 17 terimden hala ortalama 5 terimi kullanamadıkları görülmektedir. $\mathrm{Bu}$ sonuçlar doğrultusunda öğretim sürecinin öğrencilerden istenen başarıyı gerçekleştirmediğini ortaya koymaktadır.

Geometri alt öğrenme alanlarından biri olan uzamsal ilişkilerle ilgili değerlendirme etkinliğinde öğrencilerden $1,2,3,4,5,6,8,9,10,11$ ve 12. öğrencilerden istenen terimlerden "altında, içinde, dışında, üstünde, yüksekte ve alçakta" terimlerini doğru işaretlediği görülmektedir. Sadece öğrenci 7'nin "içinde, yüksek ve alçakta" terimlerini doğru işaretlediği "altında, dışında ve üstünde" terimlerini doğru işaretleyemediği görülmektedir. Öğrencilerin sınıfta yapmış oldukları değerlendirme etkinliklerinden biri seçkisiz (random) yöntemle seçilerek ve öğrencinin ismi silinerek örnek olarak verilmiştir (Bkz: Ek-1).

Ayrıca görüşme ve değerlendirme etkinliğinin incelenmesi sonucu elde edilen uzamsal ilişkilerle ilgili bulgular ve yorumlar şu şekilde özetlenebilir: Öğrencilerin öğrenme düzeyleriyle ilgili olarak yapılan görüşmelere (ilk görüş̧e ve son görüşme) bakıldığında uzamsal ilişkilerle ilgili sadece bir öğrencinin bütün terimleri kullandığı, diğer öğrencilerin ise aynı başarıyı gösteremedikleri görülmektedir. Bir öğrencinin de (öğrenci 9) öğretim süreci sonunda sadece bir terim (Illk görüşmede uzamsal ilişkilerle ilgili 9 terim kullanabilirken son görüşmede 10 terim kullanmıştır.) artırdığı görülmektedir. Bu bulgular doğrultusunda öğrencilerin öğrenme düzeyleriyle ilgili olarak şu yorumlar yapılabilir: Öğrenciler uzamsal ilişkilerle ilgili olan bütün terimleri öğrenemedikleri ifade edilebilir. Buna göre; öğrencilerin programda ön görülen öğrenme seviyelerine ulaşamadıkları ifade edilebilir.

\section{Geometrik Sekiller}

Geometri alt öğrenme alanlarından biri olan geometrik şekillerle ilgili öğretim süreci içinde öğretmenin kullanmış olduğu öğretim materyalleri ile öğrencilerin öğrenme süreçlerinin incelenmesiyle ilgili bulgular ve yorumlar aşağıdadır:

“Öğretmen: Bir, iki, üç, dört üstümü ört. Beş, altı, yedi kedi miyav dedi. Sekiz, dokuz on, omzuma kon. (ögrretmen tahtanın önünde eline topu alarak, omzuna koydu)

Öğretmen: Elimdeki ne çocuklar?

Sintf: Topppp. (Öğrenciler hep birlikte)

Öğretmen: Bu bir pinpon topu çocuklar. 
Öğretmen: Bunun ne olduğunu biliyor musunuz? (Yerküreyi göstererek)

(Sınıftaki ögrrencilerden bazıları harita bazıları da dünya cevabını verdiler.)

Öğretmen: Ne haritast?

Sinıf: Dünya haritasilullul"

$\mathrm{Bu}$ diyalogda öğretmen, geometrik şekillerle ilgili ders işleniş sürecinde üç boyutlu katı cisimleri zaman zaman öğrencilere göstermiştir. Geometrik şekillere örnek model olması için öğrencilerin çevrelerinde bulunan somut nesnelerden pinpon topunu görselleştirmek için kullanmakta olduğu görülmektedir.

"Öğretmen: (Masanın üzerindeki top ve yerküreyi göstererek);Bakın çocuklar, bu elimdeki şekiller gibi şekiller.... Göstereceğim şimdi (tepegözden resimler yansittldl)

Öğrenci: Aaaa ne güzel.

Öğretmen: Net görebiliyor musunuz?

Sinif: Evet.

Öğretmen: Şimdi burada çocuklar isterseniz önce varlıkların adlarını söyleyelim

Öğrenci: Ben dolap görüyorum.

Sinlf: Kutu, zar

Öğretmen: Nerde gördünüz bu zarl, nerde kullaniliyor?

Sinif: Tavla oyununda.

Öğretmen: Tavla oyununda kullanıllyor. Peki, bu ne?

Sinlf: Oyuncak

Öğretmen: Şurada kesme şekeri yapılmış tamam mı? Şimdi biraz yukarı kaldirıyorum. (Tepegözdeki resmi biraz yukarı kaldırır.) Şimdi bakalım. Bu bir süs kutusu!

Öğrenci: Buzdolabl

Ögretmen: Evet, buzdolabı

Ögrrenci: Çanta

Öğrenci: Pano

Öğretmen: (Resmin tümünü göstererek) Hayır, burayl sormuyorum

Sinif: Dolap

Öğretmen: Evet, dolap sinıfimızdaki dolaba benziyor mu?

Sinif: Evet." 
$\mathrm{Bu}$ diyalogdan öğretmen, geometrik şekillerle ilgili dersin işleniş sürecinde teknolojik materyal olarak tepegözü kullanmaktadır. Ayrıca sınıfta normalde bulunan eşyaları nesne olarak kullanmaktadır.

"Öğretmen: (Üç boyutlu geometrik şekillerden biri olan küpe benzeyen islak mendil kutusunu göstererek) peki, çocuklar bugün farklı bir şey göstereceğim size dikkatli bakınız. Çocuklar bu elimde gördükleriniz küreye benziyor mu?

Sinif: Hayır.

Öğretmen: (Ü̧̧ boyutlu geometrik şekillerden silindiri işaret ederek) Şu benziyor mu? Küreye

Sinif: Evet

Öğretmen: Küreye benziyor mu? (benzemediğini sözel olmayan yüz ifadesi ile çocuklara hissettirdi)

Sinif: Hayır.

Öğretmen: (Küp şeklindeki bir nesneyi göstererek) bu benziyor mu?

Sinif: Haylr.

Öğretmen: Peki, topumuz burada duruyor. Küreyi unutmuşsunuz galiba. Küreye benzeyen şekilleri neye benzetmiştik? Top gibi olan her tarafi yusyuvarlak olan düz bir kenarl var mı?

Sinif: haylullurrrr"

Bu diyalogda görüldüğü gibi öğretmen, üç boyutlu geometrik şekillerden biri olan küple ilgili dersini işlerken, öğretim materyali olarak sınıfta on anda tesadüfen bulunan nesnelerden yararlanmaktadır.

“Öğretmen: Şimdi çocuklar şu elimdekiler ne kutusu?

Sinvf: Islak mendil kutusu

Öğretmen: Islak mendil kutusu... Niçin kullanıyoruz?

Sinıf: Tuvaletten sonra elimizi silmek için.

Öğretmen: Tuvaletten sonra elimizi temizlemek için. Bunlar onların kutuları herkes buraya bakiyor lütfen bunlar birbirine benziyor mu? Çocuklar

Sinlf: hayir.

Öğretmen: (Vücut diliyle evet demeleri yönünde sözel olmayan davranışla göstererek) Birbirine benziyor mu?

Sinuf: evet.

Öğretmen: Birbirinin aynısı diyebilir miyiz?

Sint: Haylr. 
Öğretmen: (Vücut diliyle evet demeleri yönünde işaret yaparak) Birbirinin aynısı diyebilir miyiz?

Sinif: Evet.

Öğretmen: Peki, şöyle bir etrafinıza bakın. Bunlara benzeyen var mı? Çocuklar bunlara benzeyen deyince bu kutunun aynisı değil. Bakın şekil olarak (kutu üzerinde eliyle dokunarak gösterdi) bakın daha büyüğü veya daha küçüğü olabilir. Daha incesi de olabilir. Ne var buna benzeyen ne var etrafinızı izleyerek bana parmak kaldırarak söyleyin. Evet, Gökay

\section{Gökay: Çöp kovast}

Öğretmen: Çöp kovası çok güzel alkışllyoruz arkadaşınızı"

$\mathrm{Bu}$ diyalogda görüldüğü gibi öğretmenin daha önce silindir ile ilgili ders işlerken ıslak mendil kutusunu kullandığı; silindir şeklindeki somut (üç boyutlu ) modelden görsel olarak yararlandığı görülmüştür.

Bu diyaloglar doğrultusunda elde edilen geometrik şekillerle ilgili bulgular şu şekilde özetlenebilir: Öğretmenin, geometri alt öğrenme alanlarından biri olan geometrik şekillerle ilgili ders işlerken, o an sınıfta hangi materyale gözü çarptıysa ondan yararlandığı, daha önceden öğretim materyalleri hazırlayarak sınıfa getirmediği tespit edilmiştir.

$\mathrm{Bu}$ bulgular doğrultusunda geometrik şekillerle ilgili yorumlar şu şekilde özetlenebilir: Geometri alt öğrenme alanlarından biri olan geometrik şekillerle ilgili ders işleniş süreci içinde öğretmenin, kullanacağı öğretim materyallerini daha önceden belirlememesi, ders işlenmesi esnasında hangi materyal varsa o an ondan yararlanması geometrik şekillerle ilgili öğrencilerin öğrenmelerinde karmaşa oluşturmuştur. $\mathrm{Bu}$ da, öğrencilerin vermiş oldukları tepkiler ve cevaplardan anlaşılmaktadır. Örneğin "islak mendil kutusu"nun hem silindir hem de küp şeklinde olması, öğrencilerin şekillerin birbirinden farkını öğrenmesi yerine "1slak mendil" ismine yoğunlaşmalarına neden olmuştur. (öğretmenin, (1slak mendil kutusunun gösterip) bu neye benziyor? diye sorduğunda öğrencilerin islak mendil diyerek cevap verdikleri görülmektedir.) Bu durum geometrik şekillerden küple silindirin tanınması ve sınıflandırılmasına katkı sağlamamış aksine öğrencilerin kafalarının karışmasına neden olmuştur denilebilir. Öğrencilerin vermiş oldukları yanlış cevaplardan da bu açıkça anlaşılmaktadır.

Ayrıca değerlendirme etkinliği incelendiğinde geometrik şekillerle ilgili bulgular ve yorumlar şu şekilde özetlenebilir: Öğrencilerden beşi kendilerinden istenen geometrik şekilleri tanıyıp sınıflandırma yapmış; dört öğrenci ise kendilerinden istenen geometrik şekilleri hiç tanıyamamış ve sınıflandırma yapamamışlardır (Bkz: ek.1). Üç öğrencinin ise geometrik şekillerden bazılarını bazen tanıyı sinıflandırma yapabildikleri bazen de bu sinıflandırmayı yaparken karıştırdıkları tespit edilmiştir. 
Öğrencilerin öğrenme düzeyleri ile ilgili olan durumlar şöyle yorumlanabilir: Öğrencilerin geometrik şekillerle ilgili olan kişisel öğrenme düzeyleri farklılık göstermektedir. Genelde bütün öğrencilerin geometrik şekilleri iyi öğrenemedikleri söylenebilir. $\mathrm{Bu}$ duruma 3 boyutlu geometrik şekillerin sinıfta yeterince örneklenememsi ve bunların algılanmasındaki güçlük neden olmuş olabilir. Ayrıca program gereği öğretmenin üç boyutluların adlandırılması yerine bunların yüzlerindeki iki boyutlu şekiller üzerine yoğunlaşması gerekirdi.

\section{Eşlik}

Öğretmenin, geometri alt öğrenme alanlarından biri olan eşlikle ilgili öğretim süreci içinde kullandığı öğretim materyalleri ile öğrencilerin öğrenme süreçlerinin incelenmesiyle ilgili bulgular ve yorumlar aşağıdadır:

"Öğretmen: Elimde giydiğim biraz kisa geldi bu eldiveni biz tek elimizle mi kullaniyoruz?

Sinf: (sessiz kald $)$

Öğretmen: Peki, çocuklar bu sinıfta bu eldivenden hariç eşi olan ne var bir bakın eşli olan ne var sinıfimızda?

Emirhan: Şu bulutlar (slnıfin duvarındaki panodaki resimleri işaret ederek)

Öğretmen: Bulutlar birbirine eşli diyorsun. Evet Efe

Efe: Şurada ki şapkalar (dolabın üstündeki kartonlardan yapılmış konileri göstererek)

Öğretmen: Peki, bu elmayı çocuklar tahtanın bir köşesine yapıştırdım”

$\mathrm{Bu}$ diyalogda görüldüğü gibi öğretmen, kendi kullandığı eldiveni materyal olarak kullanmaktadır. Sınıfa eşlik ile ilgili incelemek ve karşılaştırma yapmak üzere başka materyal getirmemiştir.

"Öğretmen: SSimdi kitabınızda bir sayfa söylüyorum. Ders kitabınıza bakar misiniz? Zeynep, Önder, Ömer Faruk herkes bakiyor mu?

Sinif: Eveeeeet

Öğretmen: Ders kitabinızın (kitabı göstererek) şu sayfası (18 yazlyor). Bir ve sekiz burayı açıyoruz. Beyaz kâğıt da vereceğim. Kâğıdın altına bu parayı koyacaksınız. İstediğiniz tarafi koyabilirsiniz. Kâğıdın üstünden paranın olduğu yeri kurşun kalemle hafif karalayacaksınız. Çok bastırmayacaksınız. Resmin çıkmasını sağlayacağız tamam mı?

Sinif: Tamam.

Öğretmen: Sonra resmini çıkardı̆̆ınız paralara eş olanların resmini de çıkaracağız kâ̆ğ da. Parayı nereye koyacağız? Kâğıdın altına. Nereye koyacakmışı??

Sinıf: Kâğıdın altına

Ögretmen: evet" 
Bu diyalogda öğretmenin, çalışma kitabı, kâğıt, kalem ve metal para gibi araçgereçleri öğretim materyali olarak kullandığı görülmektedir. $\mathrm{Bu}$ diyaloglar doğrultusunda eşlikle ilgili elde edilen bulgular şu şekilde özetlenebilir: Öğretmenin, geometri alt öğrenme alanlarından biri olan eşlikle ilgili ders işleniş sürecinde öğretim materyali olarak eldiven, çalışma kitabı, kâğıt, kalem ve metal para gibi araç-gereçleri kullandığ 1 görülmektedir. Öğretmenin dersin işleniş süreci içinde planlı bir etkinlik için materyal olarak sınıfa sadece metal para ve A-4 kâğıdı (araştırmacının gözlemi) getirmiş olduğu görülmektedir. $\mathrm{Bu}$ bulgular doğrultusundaki eşlikle ilgili yorumlar şu şekilde özetlenebilir: Öğretmenin, dersin işlenişs süreci içinde kullanacağı materyalleri genelde planlamadığı ve hazırlamadığı görülmektedir.

Eşlikle ilgili değerlendirme etkinliğin incelenmesiyle elde edilen bulgular doğrultusunda yorumlar şu şekilde ifade edilebilir: Eşlikle ilgili olan öğrenme sürecinde sadece bir öğrencinin kendinden isteneni doğru yapamadığı, diğer bütün öğrencilerin kendilerinden isteneni doğru olarak yaptıkları tespit edilmiştir. Öğrencilerin öğrenme düzeylerin konusunda ise şunlar söylenebilir: Öğrencilerin değerlendirme etkinliğine göre eşlikle ilgili öğrenme düzeylerinin oldukça iyi seviyede oldukları söylenebilir. Bunun sebebininse okul öncesi dönemde almış oldukları etkinlik faaliyetlerin öğrenmelerine kaktı sağlamış olabileceği şeklinde ifade edilebilir.

\section{Örüntü ve Süslemeler}

Öğretmenin, geometri alt öğrenme alanlarından biri olan örüntü ve süslemelerle ilgili öğretim süreci içinde kullandığı öğretim materyalleri ile öğrencilerin öğrenme süreçlerinin incelenmesiyle ilgili bulgular ve yorumlar aşağıdadır:

"Öğretmen: (Eline aldığı kolyeyi sınıfa göstererek) Şimdi elimdekileri size gösteriyorum. Bakın. Bu nedir?

Sinif: Kolye

Öğretmen: Peki. Bu kolyede taşlar stralanmış. Ben şimdi elinize vereceğim yakından bakın. Bakın bakalım neyine göre bir sıralama yapılmış. Bak, arkaya gönder. Siz de şuna bakın. Size sonra soru soracağım. Neyine göre sıralanmış al bak, dikkatli bak incele.

Sinlf: (kolyeleri incelemektedir.)

Öğretmen: Enes, incelediğin kolyede nasil bir siralama var?

Enes:...

Öğretmen: Emirhan nasil bir siralama var?

Emirhan:...

Öğretmen: Evet (Eylül' ü işaret ederek) 


\section{Eylül: Küçük boncuk, cam boncuk}

Ögrretmen: Evet şurada küçük boncuk cam boncuk Böyle stralanmış tamam arkaya ver."

Bu diyalogdan anlaşılacağı gibi öğretmen öğretim materyali olarak bir kolyeyi sınıfa göstermiş, kısa süre için ögrrencilere dokunmaları için izin vermiştir.

"Öğretmen: Ben size şimdi kâğıt vereceğim, karton parçaları vereceğim. Karton parçalarından istediğin kadar üçgen, daire, dikdörtgenle kare kesmenizi istiyorum. Bir de ben size kesilmiş vereceğim bir miktar. Bunlarla bir örüntü oluşturmanızı istiyorum. Örüntüyü kendiniz düşüneceksiniz. İsterseniz hepsini aynı renk yani rengine göre dizebilirsiniz. Isterseniz farkls şekildekileri belli bir siraya göre dizebilirsiz. Bakalım örüntü konusunu anlamış mısınız? Önce kâğıtlarınızı veriyorum.

\section{Atakan: Öğretmenim bu kartonlardan resim mi yapacă̆ız?}

Öğretmen: Hayır çocuğum örüntü oluşturacaksin. Siralama

Öğrenci: Öğretmenim onlart yapıştıracak mıyız?

Öğretmen: (Emirhan'ın kâğıldını sinıfa göstererek) Evet. Örneğin: Emirhan ne yapmış bakın. Daire, daire, daire, üçgen, üçgen, üçgen bakın. Bakar misinız? Çalı̧̧ma böyle düzgün bir sırada olsun. Farkll şekiller de koyabilirsiniz ama düzgün sırada dağınık değil. Cünkü sıralama yapıyoruz. Siralama. Dizeceğiz ipe dizer gibi düşünün”

$\mathrm{Bu}$ diyalogda da görüldüğü gibi öğretmen, öğretim materyalli olarak öğrencilere kesilmiş karton parçaları ve etkinlik kâğıdı vermiş ve öğrencilerden bunları kendilerinin kullanmalarını istemiştir. Daha sonra ders kitabından derse devam etmiş, yani materyal olarak ders kitabını kullanmaya başlamıştır.

Bu diyaloglar doğrultusunda elde edilen örüntü ve süslemeyle ilgili bulgular şu şekilde özetlenebilir: Öğretmenin, geometri alt öğrenme alanlarından biri olan örüntü ve süslemeyle ilgili ders işlerken öğretim materyali olarak hazır halde olan bir kolyeden yararlandığı görülmektedir. Öğretmen, öğretim materyalini sınıfa göstererek kısa süre için de olsa öğrencilerin dokunmalarına izin vermiştir. Ayrıca öğretmenin, öğretim materyali olarak öğrencilere karton parçaları ve etkinlik kâğıdı verdiği öğrencilerin bu materyallerden yararlanmalarını sağladığı da görülmektedir. $\mathrm{Bu}$ bulgular doğrultusundaki örüntü ve süslemeyle ilgili yorumlar şu şekilde özetlenebilir: Öğretmenin, derse, hazır bir materyalle gelmesi, öğrencilerin ilgilerini artırmıștır.

Örüntü ve süslemeyle ilgili değerlendirme etkinliğinin incelenmesiyle elde edilen bulgular doğrultusunda yorumlar şu şekilde özetlenebilir: Bir öğrencinin doğru işaretleme yapamadığ 1 , diğer 11 öğrencinin doğru işaretleme yaptığ 1 görülmektedir. Öğrencilerin örüntü ve süslemeyle ilgili öğrenme düzeylerinin oldukça iyi olduğu söylenebilir. Yani programda, öğrencilerin, kendilerinden beklenen "bir örüntüdeki ilişkiyi belirleyebilme" ve "bir örüntüde eksik bırakılan öğeleri belirleyerek tamamlama" kazanımını gerçekleştirdikleri söylenebilir. 


\section{TARTIŞMA, SONUÇ ve ÖNERILER}

Bu bölümde araştırmanın, alt problemleriyle ile ilgili bulgular ve yorumlardan elde edilen sonuçlar ilgili literatürle karşılaştırılarak tartışılacak ve önerilere yer verilecektir.

\section{Tartışma ve Sonuçlar}

Öğretmenin, geometri alt öğrenme alanları ile ilgili ders işleniş süreci içinde öğretim materyalleri olarak sınıfta bulunan araç-gereçlerden yararlandığı görülmektedir. Örneğin tahta silgisi, sınıf dolabı, beslenme çantaları, ıslak mendil gibi araç-gereçler ve sınıfta bulunan demirbaş eşyaları kullandığı görülmektedir. Öğretmenin, ders süresinde sınıfta bulunan araç-gereçler ve demirbaş eşyaların yanı sıra futbol topu, voleybol topu, yer küre, eldiven, pinpon topu gibi materyalleri sınıfa getirip yararlandığı görülmüştür. Öğretmenin, sınıfa etkinliklerin gerçekleştirilmesi için kâğıt-kalem, metal para, çeşitli ebatlarda kesilmiş karton parçaları ve kolye gibi öğretim materyallerini getirmiş olduğu görülmüştür. Öğretmenin, teknolojik materyallerden sadece tepegözü kullandığı diğer teknolojik materyallerden yararlanmadığı görülmüştür. Sinıfta var olan projeksiyon ve dizüstü bilgisayarı kullanma imkanı olduğu halde kullanmadığı tespit edilmiş̧ir.

Öğretmenin, dersin işleniş süreci içinde kullanacağı materyalleri genelde planlamadığı ve hazırlamadığı tespit edilmiştir. Öğretmenin kullanacağı öğretim materyallerini daha önceden belirlememesi ve sinıfta olan araç-gereçlerden gözüne çarpan hangi materyal varsa o an ondan yararlanması, öğrencinin öğrenmesinde karmaşaya neden olduğu öğrencilerin vermiş oldukları tepkiler ve cevaplarından anlaşılmaktadır. Örneğin ıslak mendil kutusunun, katı cisimlerin somut modeli olarak hem silindir şeklinde hem de küp şeklinde olması, öğrencilerin şekillerin farkını öğrenmesi yerine sslak mendil ismine yoğunlaşmalarına neden olması, geometrik şekillerden küple silindirin tanınması ve sınıflandırmasına katkı sağlamadığı, öğrencilerin vermiş oldukları yanlış cevaplardan anlaşılmaktadır.

Sonuç olarak öğretmenin, dersin işleniş süreci içinde yeterince öğretim materyalinden yararlanmadığı söylenebilir. Örneğin; teknolojik materyallerden sadece tepegözü kullandığı ve diğer teknolojik materyallerden yararlanmadığı tespit edilmiştir. Buna karşın uygulanan son programda teknolojik materyallerin kullanılması ile ilgili ifadeler şu şekildedir: "Günümüzde teknoloji büyük bir hızla gelişmekte ve anlamlı matematik öğretimi için yeni firsatlar oluşturmaktadır. Bilgisayar teknolojisin gelişmesi sonucunda; öğretim yazılımlarının hem niteliği hem de niceliği artmakta, alternatifler sürekli çoğalmaktadır. Örneğin; dinamik geometri yazılımları sayesinde öğrenciler geometrik çizimleri oluşturabilmekte ya da öğretmenin hazırladığı dinamik geometrik şekiller üzerinde etkileşimli incelemeler yapabilmektedir (MEB, 2005: 18).” Öğrencilerin, tepegözle yansitılan resimlerle birlikte derse olan ilgi ve isteklerinin artması, bununla birlikte dikkatlerinin de yoğunlaşması, öğrenme isteklerinin de artığının bir göstergesi olarak ifade edilebilir. 
Öğretmenin, dersin ișleniș sürecinde yeterince öğretim materyali kullanmaması soyut olan bilgilerin yeterince somutlaştırılamadığının göstergesi olarak düşünülebilir. Programda "Kü̧̈ük yaşlardaki öğrenciler, bilgilerin somut modellerle temsil edildiği öğrenme ortamlarında daha anlamlı öğrenirler (MEB, 2005).” ifadesi ile ders içinde somutlaştırmanın önemi vurgulanmış olmasına rağmen öğretmenin, programı dikkate almadığı söylenebilir. Öğretmenin dersin işleniş sürecinde öğretim materyallerini kullanması ile ilgili literatüre de belirtilenler aşağıda şu şekilde sıralanmıştı:

Olkun ve Altun (2003), küçük yaşlarda oynanan çeşitli oyuncakların, edinilen somut deneyimlerin, geometrik ve uzamsal düşünme becerilerinin gelişimine olumlu etkisinin alan yazında (Roorda, 1994) bilinen bir durum olduğunu belirtmişlerdir. Schrier (1994), sınıf ortamı içinde geometrik şekillerle ilgili kullanılan araçgereçlerin derse katılan çocukların görsel düşünme becerilerine ve geometri kavramlarını bilişsel yapılandırmalarına katkı sağladığını vurgulamıştır. Werthessen (1999), çocukların üç boyutlu geometrik cisimlere el ile temasında zihinsel döndürme, uzamsal görselleştirme ve kendi kendine tesir açısından performansları üzerine olumlu bir etkisi olduğunu belirtmiştir.

Güven ve Karataş (2003), teknolojik materyallerin kullanılması ile yani bilgisayar yazılımları ile öğrencilerin genelde matematiğe, özelde ise geometriye yönelik görüşlerinin olumlu yönde değiştiği ve dinamik geometri ortamlarını çok yararlı bulduklarını belirtmişlerdir. Teknolojik materyallerden yaralanılarak geometrik şekillerle ilgili olarak Warren ve English (1995) de çocuklara, "Shape Makers" fonksiyonu olan (Battista, 1998), şekilleri "dinamik olarak" değiştirme imkânı verildiğinde şekil özelliklerine ilişkin anlamayı geliştirebileceklerini vurgulamıştır.

"Dersin işleniş sürecinde öğretim materyali kullanılmadığında çocuklarda öğrenme nasıl gerçekleşmektedir?” sorusuna Misretta (2000)'nın, geometri dersinde kalem ve defterden başka hiçbir şey kullanmadığında öğrencilerin, geometri konularını zor, şaşırtıcı ve karmaşık bulduklarını ayrıca onlara öğretilen konuları ezberlediklerini, öğretilenlerin ne anlama geldiğini ve amacın ne olduğunu anlamadıklarını ifade etmiştir. Bu ifaden de anlaşılacağı gibi öğretim süreci içinde öğretim materyali kullanılmadığında öğrenmenin ezberleyerek gerçekleşeceği söylenebilir.

NCTM'ye (2000) göre ise öğretmenler, geometrik şekilleri ve özelliklerini öğrencilerin keşfetmesini teşvik etmek için uygun olan çevresel yapı ve materyaller sağlamalıdır. Örneğin genç öğrenciler, çeşitli yapı bloklarını bir kenara koyarak benzer ve farklı yönlerin farkına vardırılabilirler. Şeklin özelliklerini keşfedebilmesi için en yaygın olarak kullanılabilen materyaller, ambalaj kutuları veya eşlik ve simetriyi keşfetmek için katlanmış kâğıttır. Öğrenciler, geometri tahtasına veya noktalı sayfaya geometrik şekiller oluşturup onları çizgilerle, üç boyutlu blok yapısıyla ve drama ile sunabilirler. Öğrenciler, iki ve üç boyutlu şekilleri çizimle, somut bloklarla, drama ve kelimelerle temsil etmeyi öğrenmelidirler. Öğrenciler, şekilleri parçalayıp yenisini oluşturarak şekilleri keşfetmelidirler. 
Geometri alt öğrenme alanları ile ilgili yapılan araştırmalarda farklı öğretim materyali kullanıldığında öğrencilerin öğrenmelerinde bir artış gerçekleştĭgi vurgulanmıştır. Örneğin Asaf (1985), "Logo" kullanarak öğrencilerin, geometrik cisimlerin özelliklerini daha iyi anladıklarını, şekiller arasındaki ilişkileri daha rahat kurabildiklerini ve bu aracın, öğrencilerin motivasyonunu arttırdığını saptamıştır. Buna paralel olarak Scally (1990), "Logo Programı”na göre öğretim yapıldığında öğrencilerin öğrenme düzeylerinde bir artma olduğunu belirtmiştir.

\section{Öneriler}

Bir öğretmen ve 12 öğrenciyle yapılan bu çalışma örneklem açısından yeterlidir. Fakat daha geniş örneklem alınarak daha çok öğretmen ve daha çok öğrenci dâhil edilerek daha geniş kapsamlı araştırmalar yapılabilir. Çünkü bu durum bu sınıf için geçerlidir. Bilimsel olarak daha fazla veri elde edip daha fazla bilime 1şık tutmak için genişletilebilir. Matematik dersi öğretim programında yer alan 1.sınıf alt öğrenme alanların hepsi ile ilgili olarak da benzer bir araştırma yapılabilir.

Uygulanmakta olan 2004 İlköğretim Matematik Dersi (1-5) Öğretim Programının özel okullar ile devlet okullarında uygulanması nasıl gerçekleştirildiği (öğretim materyallinin sınıf içinde kullanımı ile ilgili olarak) karşılaştırılabilir. Bununla birlikte öğretmenlerin mesleki kıdemlerine göre programı uygulamalarında bir değişiklik olup olmadığına da bakılmak için aynı araştırma gerçekleştirilebilir.

$\mathrm{Bu}$ yaştaki çocukların somut işlem döneminde olduğu düşünüldüğünde ise öğretim sürecinde öğrenmelerinin gerçekleşmesi için daha çok somut materyalden yaralanılması gerekmektedir. Öğrencilerin daha çok somut materyalle karşılaşmaları ve kullanmaları için matematik sınıfları kurulabilir. Ya da matematik öğretiminde yaygin olarak kullanılan somut materyaller, modeller siniflarda bulundurularak dersin amaçları doğrultusunda kullanılmaları sağlanabilir. 


\section{KAYNAKÇA}

Altın Eğitim, (2005), Altın Eğitim <http://www.altinegitim.k12.tr/site/duyuru/8>. (2005.12.18).

Ardahan, H. ve Ersoy, Y. (2004). İlköğretim Okullarında Kesirlerin Öğretimi-II. <http://www.matder.org.tr/>. (2005.10.18).

Balım, G. A. ve Kesecioglu, T. (2004). Observeations on the Science Teacher Training Programs in Turkey and Hungary. Ĕgitim Araşttrmalart: Eurasian Journal of Educational Research. S:17. Ankara.

Bulut, S. (2004). Illköğretim Programı Yeni Yaklaşımlar Matematik (1-5 sınıf ). Millî Eğitim. Ankara.

Cohen, L. and Manion, L. (1992). Research Methods in Education. (3. edition) Routledge Press. London and New York.

Ekiz, D. (2003). Eğitimde Araştirma Yöntem ve Metodlarına Giriş. Anı Yayıncılık. Ankara.

Güven, B. ve Karataş, İ. (2003). Dinamik Geometri Yazılımı Cabrı ile Geometri Öğrenme: Öğrenci Görüşleri. The Turkish Online Journal of Educational Technology - TOJET January April ISSN: 1303-6521 Volume 2, Issue 2, Article 10. <www.tojet.net/articles/2210.htm>. (2005. 03. 24).

MEB (Millî Eğitim Bakanlığı), TTKB (Talim ve Terbiye kurul Başkanlığı). (2005). Ilkögrretim Matematik Dersi (1-5) Öğretim Programı. Devlet Kitapları Müd. Bas. Evi. Ankara.

Merriam, S. B. (1998). Qualitative Research and Case Study Applications in Education. Jossey-Bass Publishers. San Francisco.

Mertens, D. (1998). Research Methods in Education and Psychology. Sage Publications. London.

Misretta, R. M. (2000). Enhancing Geometric Reasoning. Adolescence, 35-138: 365-380. (2002 EBSCO Research Database).

NCTM. (National Council of Teachers of Mathematics). (2000). Principles and Standards for School Mathematics. Reston. VA.

NCTM. (National Council of Teachers of Mathematics). (2000). Spahe and Space in Geometry.

<http://www.learner.org/teacherslab/math/geometry/shape/index.html\#standards>. (2006.01.03).

NCTM. (National Council of Teachers of Mathematics). (2000). Curriculum and Evaluation Standards for School Mathematics. 1997-1998 Handbook: NCTM Goals, Leaders, and Positionstatements, Reston. VA: The Council.

Olkun, S. ve Altun, A. (2003). İlköğretim Öğrencilerinin Bilgisayar Deneyimleri ile Uzamsal Düşünme ve Geometri Başarıları Arasındaki İlişki. The Turkish Online Journal of Educational Technology - TOJET October 2003 ISSN: 1303-6521 Volume 2. Issue 4. Article 13. 
Olkun, S. ve Aydoğdu, T. (2003). Üçüncü Uluslararası Matematik ve Fen Araştırması (TIMSS) Nedir? Neyi Sorgular? Örnek Geometri Soruları ve Etkinlikler. İlköğretim Online, 2(1), 28-35. [Online] <http://ilkogretimonline.org.tr/vol2say1/index.htm>. (2005.02.21).

Pesen, C. (2005). Yapılandırmacı Öğrenme Yaklaşımına Göre Yeni İlköğretim Matematik Öğretim Programı'nın Değerlendirilmesi. Yeni İlköğretim Öğretim Programlarının Değerlendirme Sempozyumu. 14-16 Kasım 2005 Erciyes Üniversitesi. Kayseri.

Plowman, L. (1999), Using Video for Observing Interaction in the Classroom, The Scottish Council for Research in Education, http://www.scre.ac.uk, (2005.10.12).

PISA. (Program for International Student Assessment). (2003). Program for International Student Assessment. Meb- earged. $<$ http://earged.meb.gov.tr/olcmedeg/ulsars/pisa/onrapor.pdf $>$. (2005.12.18)

Scally, S. P. (1990). The Impact of Experience in a Logo Learning Environment on Adolescents' Understanding of Angle: a van Hiele Based Clinical Assessments. 52: 3.Dissertation Abstracts International.

Schrier, D. M. (1994). The Development of Young Children's Geometry Thinking in a Mediated Kindergarten Classroom Environment. Ph. D Thesis. State University Of New York At Buffalo. U.S.A.

Strauss, A. and Gorbin, J. (1990). Basics of Qualitative Reseach: Grounded Theory Procedures and Techniques. SAGE. London.

Strauss, A. and Gorbin, J. (1998). Basics of Qualitative Reseach: Procedures and Techniques for Grounded Theory. SAGE. London.

Strauss, A. (1987). Qualitative Analysis for Social Scientists. MA; CambridgeUniversity Press. Cambridge.

Yeşildere, S. (2006). Farklı Matematiksel Güce Sahip İlköğretim 6, 7 ve 8. Sinıf Öğrencilerinin Matematiksel Düşünme ve Bilgiyi Oluşturma Süreçlerinin İncelenmesi. Yayınlanmamış Doktora Tezi. Dokuz Eylül Üniversitesi. Eğitim Bilimler Enstitüsü. İzmir.

Yıldırm, A. ve Şimşek, H. (2005). Sosyal Bilimlerde Nitel Araştırma Yöntemi. Seçkin Yayıncılık. Ankara.

Warrer, E. and English, L. (1995). Facility With Plane Shapes: A Multifaceted Skill. Educational studies in mathematics. 28(4). 365-383.

Werthessen, H. (1999). Instruction in Spatial Skills And its Effect On Self-Efficacy And Achievement in Mental Rotation And Spatial visualization. Ph. D.Thesis, Columbia Üniversty. <http://wwwlib.umi.com/dissertations/fullcit/9634439>. (2005.03.24). 
Geometri Alt Öğrenme Alanlarının Öğretiminde Kullanılan Öğretim...

323

Ek:1. Değerlendirme Etkinliği

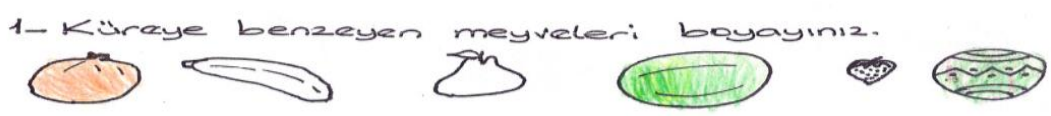

2 - Prizmaya benzeyence-i boyayiniz.

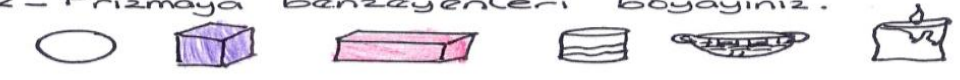

3- Koniye benzeyenleri isaretleyiniz.
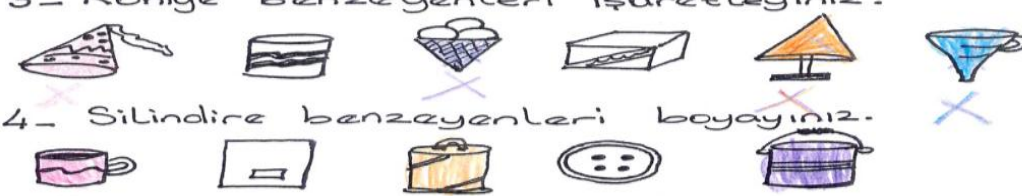

5- Öruntïye göre bos olan yerde hangivarlik

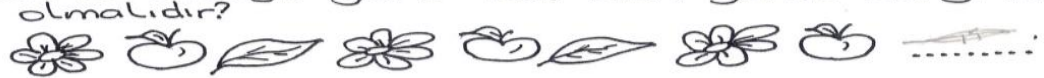

6- Tabagin iaindeki meyveleri boyayiniz.
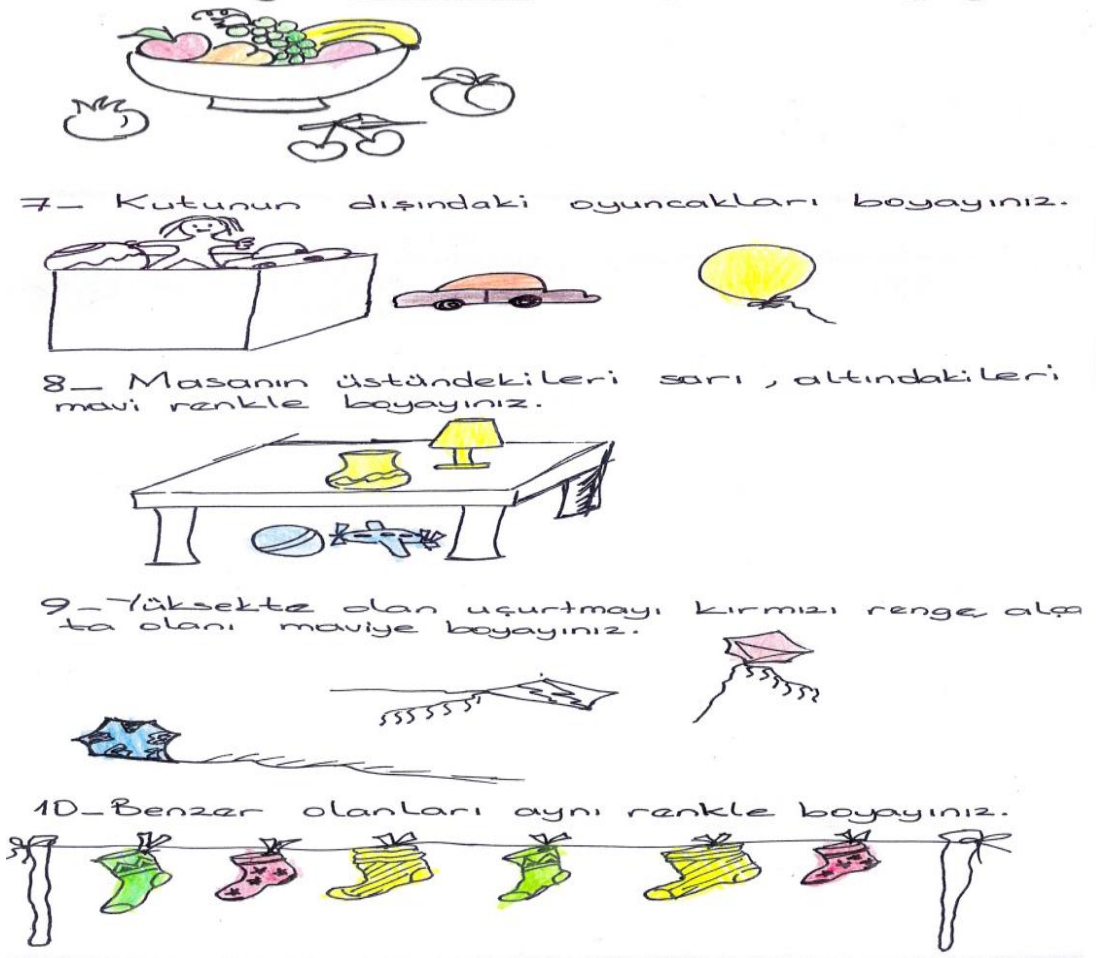